\title{
USAGE OF RECLAIMED ASPHALT PAVEMENT AS A MIXTURE MATERIAL OF ASPHALT CONCRETE - WEARING COURCE (ACWC)
}

\author{
Ratna Handayani ${ }^{1}$, Ahmad Faathir Wicaksono ${ }^{2}$ \\ ${ }^{1,2}$ Junior Road and Bridge Engineer, East Java Province Road Agency, Surabaya, Indonesia \\ E-mail : ratnay1999@gmail.com
}

\begin{abstract}
The objective of this research is to utilize Reclaimed Asphalt Pavement (RAP) as a mixture of hot asphalt $A C$-WC type. The new additional material is required such as an aggregate and asphalt to meet the technical performance which is based on Specification Bina Marga 2018 Revision 2. This research is started by analyzing the RAP. The result of RAP extraction process are aggregates and asphalt. Grading on aggregate were conducted for required grading envelope. If it failed to qualify for required grading envelope, new aggregate and new asphalt is needed. Therefore, the AC-WC mixture was composed by mixing with a variation of RAP which is $10 \%, 20 \%$ and $30 \%$. From all of the mixing composition, only mixture with $30 \%$ of RAP and $70 \%$ of new materials is recommended for hot mixture which fulfilling the engineering criteria requirements.
\end{abstract}

Keywords: Asphalt Concrete - Wearing Course (AC-WC), Reclaimed Asphalt Pavement (RAP), grading envelope

\section{Introduction}

The East Java Province is responsible to maintain the condition of 1769 kilometers road, authorized as the road province [1]. The type of road is flexible pavement which needs the maintenance both potholes patching and overlaying annually. From all of road, only one third of the road reconstruction which had been scrapped resulting on the Reclaimed Asphalt Pavement (RAP). The volume of this RAP wasted material in East Java Province is approximately $50.000 \mathrm{~m}^{3}$. The RAP wasted material can be used as the mixture of hot asphalt by adding the new material.

RAP contains the asphalt and aggregate which can be used as the substitute material for the new hot mix asphalt for the flexible pavement. The usage of RAP wasted material could save the natural resources such as the aggregate, sand and asphalt decreasing the natural disaster and damage caused by the mining process[2]. The RAP material can be used for simple purposes such as road shoulder material, road material for patching potholes, asphalt underlayer material as well as for purposes that require high technical specifications such as hot or cold mix[3]. In addition, some of the benefits of using RAP are: saving energy, maintaining environmental balance, reducing construction costs, and protecting aggregates and binders on old pavements. The Crack damage can be minimized by using this RAP mixture [4]. The use of RAP for the ACWC type still meets the requirements of the Technical specifications with certain materials and materials[5].

To optimize the usage of RAP material in East Java Province, this research is conducted as an effort to implement the RAP as the mixture material of Asphalt Concrete - Wearing Course (ACWC) using asphalt Pen 60/70. So that the author wants to know about the characteristic of RAP (aggregate and asphalt) resulted from scrapping pavement material, and How to optimized the usage of RAP as the pavement material. 


\section{Material and Methods}

\subsection{Research Method}

The steps of the research are shown below:

1. Analyzing the RAP to obtain the aggregate and asphalt characteristic as well as the grading of the material whether fulfilling the envelope required. If the grading of aggregate and asphalt is not meet the criteria, the new material is added.

2. Making the composition of mix design for Asphalt Concrete- Wearing Course (AC-WC) with adding of RAP variation.

\subsection{Research Material}

The material of the research is shown below:

1. The RAP material is obtained from scrapping one of the road in East Java Province

2. The new aggregate from the local Asphalt Mixing Plant (AMP).

3. The Asphalt Pen 60/70.

\section{Result and Discussion}

The result of test shows:

\subsection{RAP and New Material (Aggregate and Asphalt)}

Table 1. Result of RAP Material (Aggregate)

\begin{tabular}{|c|l|c|c|}
\hline No & Type of test & Specification & Test Result \\
\hline 1. & Specific gravity gr $/ \mathrm{cm}^{3}$ & - & 2,6 \\
\hline 2. & Water absorption (\%) & - & 1,42 \\
\hline
\end{tabular}

Source: Test Results

Table 2 shows that the result of test had fulfilled the specification required.

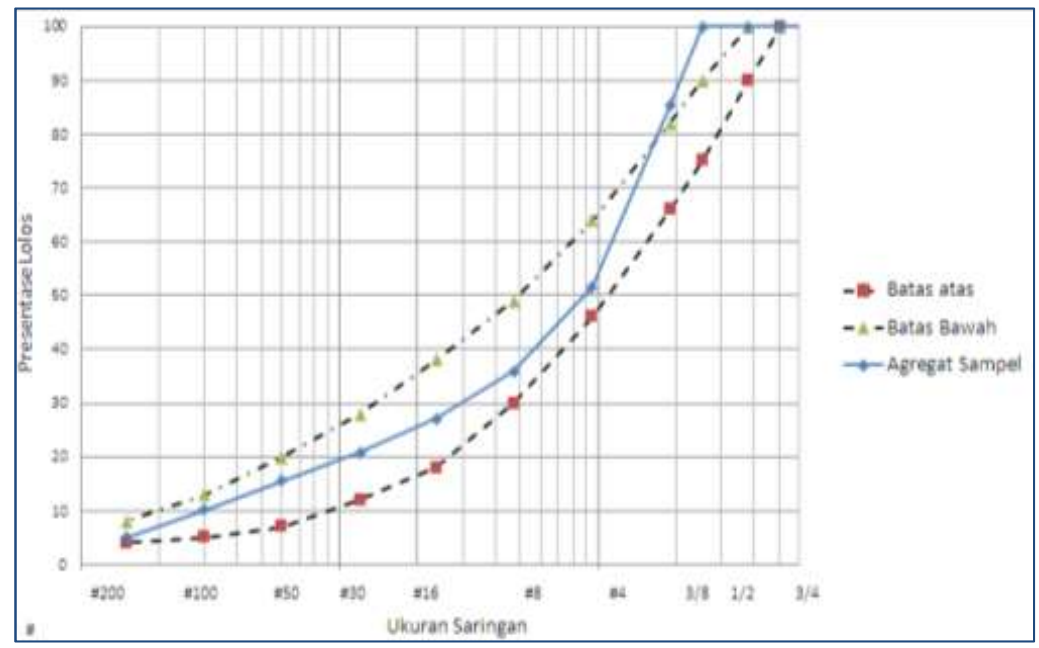

Figure 1. RAP Aggregate Grading

Figure 1 shows that the RAP aggregate grading is not fulfilled the specification required since the material passed sieve number $1 / 2$ was not accepted on the grading envelope. To achieve the grading envelope, the new material is added. 
Table 2. Result of RAP Material (Asphalt)

\begin{tabular}{|c|c|c|c|}
\hline No & Type of test & Specification & Test Result \\
\hline 1. & Asphalt content in the mixture (\%) & - & $4 \%$ \\
\hline
\end{tabular}

Source: Test Results

Table 2 shows that the result of the test had fulfilled the requirement except the penetration test result with only 49 from $60-70$ which required.

Table 3. Result of the New Material (Aggregate)

\begin{tabular}{|c|l|c|l|}
\hline No & \multicolumn{1}{|c|}{ Type of test } & $\begin{array}{c}\text { Specificatio } \\
\mathbf{n}\end{array}$ & \multicolumn{1}{|c|}{ Test Result } \\
\hline 1. & Abrasion Test (\%) & Maks 40\% & 30 \\
\hline 2. & Aggregate Stickiness Test (\%) & Min 95\% & 95 \\
\hline 3. & $\begin{array}{l}\text { Density Test }(\mathrm{gr} / \mathrm{cm} 3) \text { and Water Absorption } \\
(\%)\end{array}$ & - & 1.64 \\
\hline
\end{tabular}

Source: Test Result

Table 3 shows that the result of the test had fulfilled the requirements.

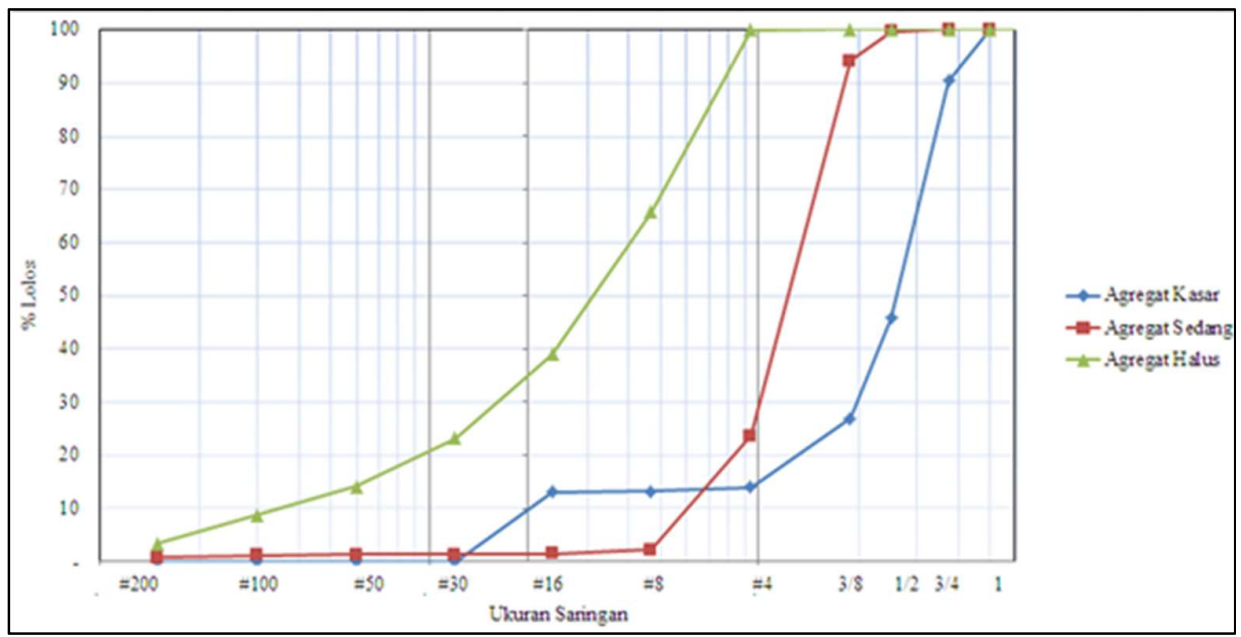

Figure 2. New Aggregate Gradations

Figure 2 shows that the course, medium and fine aggregate grading can be used as the added material for RAP so that the combined grading aggregate fulfills the specification required.

Table 4. Result of New Material (Asphalt)

\begin{tabular}{|l|l|l|l|}
\hline No & Type of test & $\begin{array}{c}\text { Requiremen } \\
\mathbf{t}\end{array}$ & Test Result \\
\hline 1. & Penetration at $25^{\circ} \mathrm{C}(0.1 \mathrm{~mm})$ & $60-70$ & 62 \\
\hline 2. & Viscosity $135^{\circ} \mathrm{C}(\mathrm{cSt})$ & $\geq 300$ & 393 \\
\hline 3. & Softening Point $\left({ }^{\circ} \mathrm{C}\right)$ & $\geq 48$ & 49,1 \\
\hline 4. & Ductility at $25^{\circ} \mathrm{C}(\mathrm{cm})$ & $\geq 100$ & $>140$ \\
\hline 5. & Flash Point $\left.{ }^{\circ} \mathrm{C}\right)$ & $\geq 232$ & 240 \\
\hline 6. & Solubility of Trichlorethylene $(\%)$ & $\geq 99$ & 99,82 \\
\hline 7. & Specific gravity & $\geq 1,0$ & 1,03 \\
\hline 8 & Weight Loss $(\%)(\mathrm{TFOT})$ & $\leq 0.8$ & $0,21 \%$ \\
\hline 9 & Penetration at $25^{\circ} \mathrm{C}(\%)(\mathrm{TFOT})$ & $\geq 54$ & $58 \%$ \\
\hline
\end{tabular}




\begin{tabular}{|l|l|l|l|}
\hline No & Type of test & $\begin{array}{c}\text { Requiremen } \\
\mathbf{t}\end{array}$ & Test Result \\
\hline 10 & Ductility at $25^{\circ} \mathrm{C}(\mathrm{cm})($ TFOT) & $\geq 100$ & 100 \\
\hline
\end{tabular}

Table 4 shows that the result of the test using asphalt Pen 60/70 had fulfilled the requirement.

\subsection{Mix Design Composition for AC-WC mixture.} of:

To fulfill the grading envelope according to specifications, the new aggregates added consist

- Aggregate coarse (10-20)

- Aggregate medium (5-10)

- Fine aggregate (0-5)

Based on the gradation of RAP and the gradation of new materials, the composition of the AC-WC mixture is made as follows: (10\% RAP; $90 \%$ new material), (20\% RAP; $80 \%$ new material) and (30\% RAP; $70 \%$ new material).

\subsubsection{Gradient Aggregate Combined with RAP 10\%, New Material 90\%}

Based on the RAP aggregate grading and the CA, MA, FA gradations, the compilation of the combined aggregate grading is carried out by trial and error of several compositions so that the combined aggregate gradations are included in the "grading envelope". As for the compilation of combined aggregate grading with RAP 10\%, 90\% new material is presented in Table 6 and Figure 3. 4.2 Mixture Design Composition for AC-WC

To fulfill the grading envelope as the specification the new aggregate which was added contains of as

follows:

$\begin{array}{ll}\text { - } & \text { Coarse aggregate (10-20) } \\ \text { - } & \text { Medium aggregate (5-10) } \\ & \text { Fine aggregate (0-5) }\end{array}$

Based on the RAP grading and new material aggregate, the mixture composition of AC-WC is made as follows: 10\% RAP; $90 \%$ New Material), 20\% RAP; $80 \%$ New Material and 30\% RAP; $70 \%$ New Material.

\subsubsection{Combined Aggregate Grading with $10 \%$ RAP, 90\% New Material}

The result of combined aggregate grading with $10 \%$ RAP, $90 \%$ New Material is shown on Table 5 and Figure 3 below.

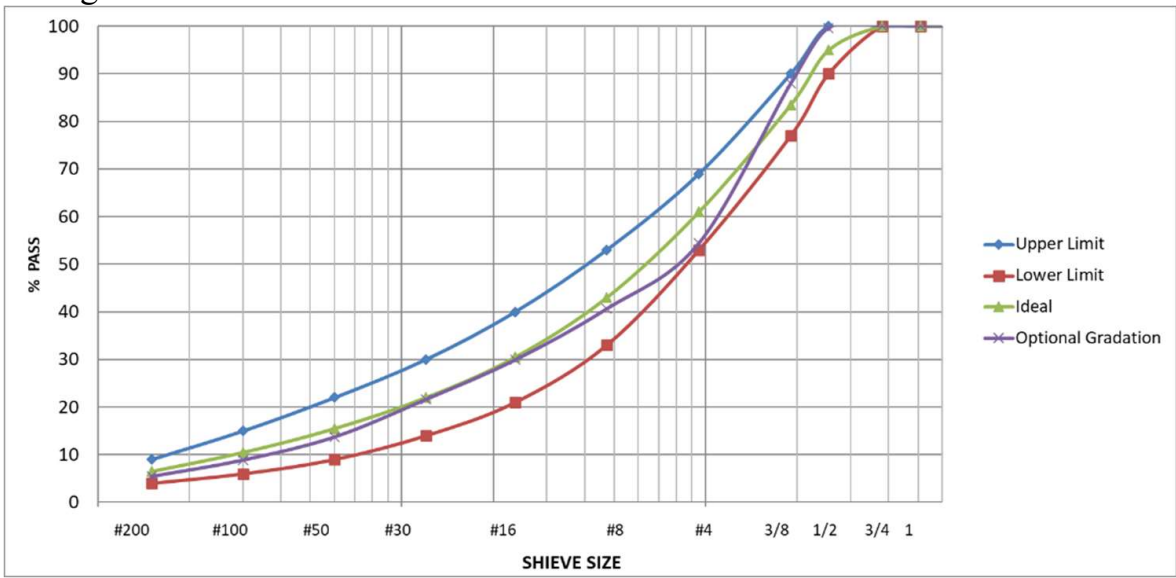

Figure 3. Combined Aggregate Gradation with RAP 10\%, New Material 90\%

Figure 3 shows that the combined grading had fulfilled the specification required. 
Table 5. Gradient Aggregate Combined with RAP 10\%, New Material 90\%

\begin{tabular}{|c|c|c|c|c|c|c|c|c|c|c|c|}
\hline \multirow{2}{*}{ Description } & composition & \multicolumn{10}{|c|}{ Shieve Size } \\
\hline & $(\%)$ & \multicolumn{10}{|c|}{ (\% pass) } \\
\hline Inch & & $3 / 4 "$ & $1 / 2$ & $3 / 8 "$ & $\# 4$ & $\# 8$ & $\# 16$ & $\# 30$ & $\# 50$ & $\# 100$ & $\# 200$ \\
\hline $\mathrm{Mm}$ & & 19.0 & 12.5 & 9.5 & 4.75 & 2.36 & 1.18 & 0.600 & 0.300 & 0.150 & 0.075 \\
\hline \multicolumn{12}{|l|}{$\begin{array}{l}\text { Aggregate Gradient } \\
\text { Data }\end{array}$} \\
\hline - RAP & & 100 & 100 & 81.58 & 45.25 & 28.67 & 22.76 & 18.27 & 14.31 & 11.43 & 8.00 \\
\hline $\begin{array}{l}\text { - Coarse } \\
\text { Aggregate (CA) }\end{array}$ & & 100.00 & 96.48 & 34.52 & 9.78 & 2.02 & 0.13 & 0.00 & 0.00 & 0.00 & 0.00 \\
\hline $\begin{array}{l}\text { - Medium } \\
\text { Aggregate (MA) }\end{array}$ & & 100 & 100.00 & 91.66 & 18.65 & 5.12 & 3.62 & 1.69 & 1.12 & 0.42 & - \\
\hline $\begin{array}{l}\text { - Fine Aggregate } \\
\text { (FA) }\end{array}$ & & 100 & 100 & 100 & 97.85 & 82.16 & 59.32 & 41.89 & 24.15 & 13.66 & 6.49 \\
\hline - Cement & & 100 & 100 & 100 & 100 & 100 & 100 & 100 & 100 & 100 & 100 \\
\hline \multicolumn{12}{|l|}{$\begin{array}{l}\text { Aggregate } \\
\text { combination }\end{array}$} \\
\hline - RAP & 10 & 10 & 10 & 8.16 & 4.53 & 2.87 & 2.28 & 1.83 & 1.43 & 1.14 & 0.80 \\
\hline $\begin{array}{l}\text { - Coarse } \\
\text { Aggregate (CA) }\end{array}$ & 11 & 11.00 & 10.61 & 3.80 & 1.08 & 0.22 & 0.01 & -1 & - & - & \\
\hline $\begin{array}{l}\text { - Medium } \\
\text { Aggregate (MA) }\end{array}$ & 36 & 36.00 & 36.00 & 33.00 & 6.71 & 1.84 & 1.30 & 0.61 & 0.40 & 0.15 & \\
\hline $\begin{array}{l}\text { - Fine Aggregate } \\
\text { (FA) }\end{array}$ & 41 & 41.00 & 41.00 & 41.00 & 40.12 & 33.69 & 24.32 & 17.17 & 9.90 & 5.60 & 2.66 \\
\hline - Cement & 2 & 2.00 & 2.00 & 2.00 & 2.00 & 2.00 & 2.00 & 2.00 & 2.00 & 2.00 & 2.00 \\
\hline Total Mix & 100 & 100.00 & 99.61 & 87.95 & 54.43 & 40.62 & 29.91 & 21.61 & 13.74 & 8.89 & 5.46 \\
\hline \multicolumn{12}{|l|}{$\begin{array}{l}\text { Envelope Gradation } \\
\text { Spec }\end{array}$} \\
\hline Maks. & & 100 & 100 & 90 & 69 & 53.0 & 40.0 & 30.0 & 22.0 & 15 & 9 \\
\hline Min & & 100 & 90 & 77 & 53 & 33 & 21 & 14 & 9 & 6 & 4 \\
\hline Ideal Gradation & & 100.0 & 95.0 & 83.5 & 61.0 & 43.0 & 30.5 & 22.0 & 15.5 & 10.5 & 6.5 \\
\hline
\end{tabular}

Source: Test Results

Based on table 6 shows that the best composition to obtain the envelope combined grading consists of RAP $10 \%$, course aggregate $11 \%$, medium aggregate $36 \%$, fine aggregate $41 \%$ and cement $2 \%$.

\subsubsection{Combined Aggregate Grading with $20 \%$ RAP, $80 \%$ New Material}

The result of combined Aggregate Grading with $20 \%$ RAP, $80 \%$ New Material is shown on Table 6 and Figure 4 below.

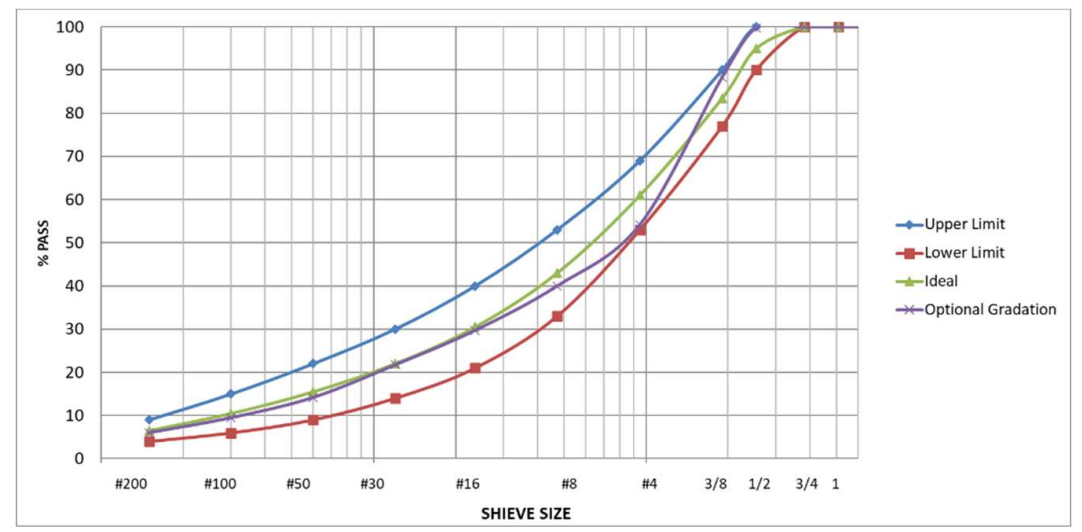

Figure 4 Combined Aggregate Gradation with 20\% RAP, 80\% New Material Figure 4 shows that the combined grading had fulfilled the specification required. 
Table 6. Combined Aggregate Grading with $20 \%$ RAP, 80\% New Material

\begin{tabular}{|c|c|c|c|c|c|c|c|c|c|c|c|}
\hline \multirow{2}{*}{ Description } & composition & \multicolumn{10}{|c|}{ Shieve Size } \\
\hline & (\%) & \multicolumn{10}{|c|}{ (\% pass) } \\
\hline Inch & & $3 / 4 "$ & $1 / 2 "$ & $3 / 8^{\prime \prime}$ & $\# 4$ & $\# 8$ & $\# 16$ & $\# 30$ & $\# 50$ & $\# 100$ & $\# 200$ \\
\hline $\mathrm{Mm}$ & & 19.0 & 12.5 & 9.5 & 4.75 & 2.36 & 1.18 & 0.600 & 0.300 & 0.150 & 0.075 \\
\hline \multicolumn{12}{|l|}{$\begin{array}{l}\text { Aggregate } \\
\text { Gradient Data }\end{array}$} \\
\hline - RAP & & 100 & 100 & 81.58 & 45.25 & 28.67 & 22.76 & 18.27 & 14.31 & 11.43 & 8.00 \\
\hline $\begin{array}{l}\text { - Coarse } \\
\text { Aggregate (CA) }\end{array}$ & & 100.00 & 96.48 & 34.52 & 9.78 & 2.02 & 0.13 & 0.00 & 0.00 & 0.00 & 0.00 \\
\hline $\begin{array}{l}\text { - Medium } \\
\text { Aggregate (MA) }\end{array}$ & & 100 & 100.00 & 91.66 & 18.65 & 5.12 & 3.62 & 1.69 & 1.12 & 0.42 & - \\
\hline $\begin{array}{l}\text { - Fine Aggregate } \\
\text { (FA) }\end{array}$ & & 100 & 100 & 100 & 97.85 & 82.16 & 59.32 & 41.89 & 24.15 & 13.66 & 6.49 \\
\hline - Cement & & 100 & 100 & 100 & 100 & 100 & 100 & 100 & 100 & 100 & 100 \\
\hline \multicolumn{12}{|l|}{$\begin{array}{l}\text { Aggregate } \\
\text { combination }\end{array}$} \\
\hline - RAP & 20 & 20 & 20 & 16.32 & 9.05 & 5.73 & 4.55 & 3.65 & 2.86 & 2.29 & 1.60 \\
\hline $\begin{array}{l}\text { - Coarse } \\
\text { Aggregate (CA) }\end{array}$ & 8 & 8.00 & 7.72 & 2.76 & 0.78 & 0.16 & 0.01 & & & & \\
\hline $\begin{array}{l}\text { - Medium } \\
\text { Aggregate (MA) }\end{array}$ & 33 & 33.00 & 33.00 & 30.25 & 6.15 & 1.69 & 1.19 & 0.56 & 0.37 & 0.14 & - \\
\hline $\begin{array}{l}\text { - Fine Aggregate } \\
\text { (FA) }\end{array}$ & 37 & 37.00 & 37.00 & 37.00 & 36.20 & 30.40 & 21.95 & 15.50 & 8.94 & 5.05 & 2.40 \\
\hline - Cement & 2 & 2.00 & 2.00 & 2.00 & 2.00 & 2.00 & 2.00 & 2.00 & 2.00 & 2.00 & 2.00 \\
\hline Total Mix & 100 & 100.00 & 99.72 & 88.33 & 54.19 & 39.98 & 29.71 & 21.71 & 14.17 & 9.48 & 6.00 \\
\hline \multicolumn{12}{|l|}{$\begin{array}{l}\text { Envelope Gradation } \\
\text { Spec }\end{array}$} \\
\hline Maks. & & 100 & 100 & 90 & 69 & 53.0 & 40.0 & 30.0 & 22.0 & 15 & 9 \\
\hline Min & & 100 & 90 & 77 & 53 & 33 & 21 & 14 & 9 & 6 & 4 \\
\hline Ideal Gradation & & 100.0 & 95.0 & 83.5 & 61.0 & 43.0 & 30.5 & 22.0 & 15.5 & 10.5 & 6.5 \\
\hline
\end{tabular}

Source: Test Results

Based on Table 6 shows that the best composition to obtain the envelope combined grading consists of RAP $20 \%$, course aggregate $8 \%$, medium aggregate $33 \%$, fine aggregate $37 \%$ and cement $2 \%$.

\subsubsection{Combined Aggregate Grading with $30 \%$ RAP, 70\% New Material}

The result of combined aggregate grading with $30 \%$ RAP, $70 \%$ New Material is shown on Table 7 and Figure 5 below. 
Table 7. Combined Grades with RAP 30\%, 70\% New Material

\begin{tabular}{|c|c|c|c|c|c|c|c|c|c|c|c|}
\hline \multirow{2}{*}{ Description } & \multirow{2}{*}{$\begin{array}{c}\text { composition } \\
(\%)\end{array}$} & \multicolumn{10}{|c|}{ Shieve Size } \\
\hline & & \multicolumn{10}{|c|}{ (\% pass) } \\
\hline Inch & & $3 / 4^{\prime \prime}$ & $1 / 2^{\prime \prime}$ & $3 / 8^{\prime \prime}$ & $\# 4$ & $\# 8$ & $\# 16$ & $\# 30$ & $\# 50$ & $\# 100$ & $\# 200$ \\
\hline $\mathrm{Mm}$ & & 19.0 & 12.5 & 9.5 & 4.75 & 2.36 & 1.18 & 0.600 & 0.300 & 0.150 & 0.075 \\
\hline \multicolumn{12}{|l|}{$\begin{array}{l}\text { Aggregate } \\
\text { Gradient Data }\end{array}$} \\
\hline - RAP & & 100 & 100 & 81.58 & 45.25 & 28.67 & 22.76 & 18.27 & 14.31 & 11.43 & 8.00 \\
\hline $\begin{array}{l}\text { - Coarse } \\
\text { Aggregate (CA) }\end{array}$ & & 100.00 & 96.48 & 34.52 & 9.78 & 2.02 & 0.13 & 0.00 & 0.00 & 0.00 & 0.00 \\
\hline $\begin{array}{l}\text { - Medium } \\
\text { Aggregate (MA) }\end{array}$ & & 100 & 100.00 & 91.66 & 18.65 & 5.12 & 3.62 & 1.69 & 1.12 & 0.42 & - \\
\hline $\begin{array}{l}\text { - Fine Aggregate } \\
\text { (FA) }\end{array}$ & & 100 & 100 & 100 & 97.85 & 82.16 & 59.32 & 41.89 & 24.15 & 13.66 & 6.49 \\
\hline - Cement & & 100 & 100 & 100 & 100 & 100 & 100 & 100 & 100 & 100 & 100 \\
\hline \multicolumn{12}{|l|}{$\begin{array}{l}\text { Aggregate } \\
\text { combination }\end{array}$} \\
\hline - RAP & 30 & 30 & 30 & 24.47 & 13.58 & 8.60 & 6.83 & 5.48 & 4.29 & 3.43 & 2.40 \\
\hline $\begin{array}{l}\text { - Coarse } \\
\text { Aggregate (CA) }\end{array}$ & 8 & 8.00 & 7.72 & 2.76 & 0.78 & 0.16 & 0.01 & & & & \\
\hline $\begin{array}{l}\text { - Medium } \\
\text { Aggregate (MA) }\end{array}$ & 25 & 25.00 & 25.00 & 22.92 & 4.66 & 1.28 & 0.91 & 0.42 & 0.28 & 0.11 & \\
\hline $\begin{array}{l}\text { - Fine Aggregate } \\
\text { (FA) }\end{array}$ & 35 & 35.00 & 35.00 & 35.00 & 34.25 & 28.76 & 20.76 & 14.66 & 8.45 & 4.78 & 2.27 \\
\hline - Cement & 2 & 2.00 & 2.00 & 2.00 & 2.00 & 2.00 & 2.00 & 2.00 & 2.00 & 2.00 & 2.00 \\
\hline Total Mix & 100 & 100.00 & 99.72 & 87.15 & 55.27 & 40.80 & 30.51 & 22.57 & 15.03 & 10.32 & 6.67 \\
\hline \multicolumn{12}{|l|}{$\begin{array}{l}\text { Envelope Gradation } \\
\text { Spec }\end{array}$} \\
\hline Maks. & & 100 & 100 & 90 & 69 & 53.0 & 40.0 & 30.0 & 22.0 & 15 & 9 \\
\hline Min & & 100 & 90 & 77 & 53 & 33 & 21 & 14 & 9 & 6 & 4 \\
\hline Ideal Gradation & & 100.0 & 95.0 & 83.5 & 61.0 & 43.0 & 30.5 & 22.0 & 15.5 & 10.5 & 6.5 \\
\hline
\end{tabular}

Source: Test Results

Based on table 8 shows that the best composition to obtain the envelope combined grading consists of RAP $30 \%$, course aggregate $8 \%$, medium aggregate $25 \%$, fine aggregate $35 \%$ and cement $2 \%$.

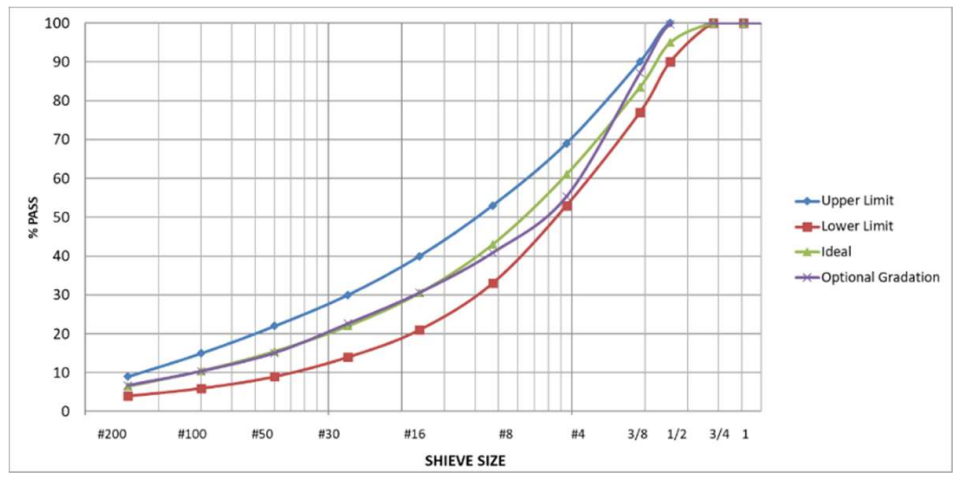

Figure 5. Combined Aggregate Gradation with RAP 30\%, 70\% New Material

Figure 5 shows that the combined grading had fulfilled the specification required.

\subsubsection{New Asphalt Bitumen Content Added}

Most of the asphalt bitumen content comes from the RAP, the calculation of the new asphalt Pen $60 / 70$ which has to be added to fulfill the empirical asphalt bitumen content in mixture is shown on 
Table 8 and Figure 6. Calculation of added bitumen content is based on NAPA Education Foundation, 1996[11].

Table 8. Asphalt Bitumen Content Added in Mixture

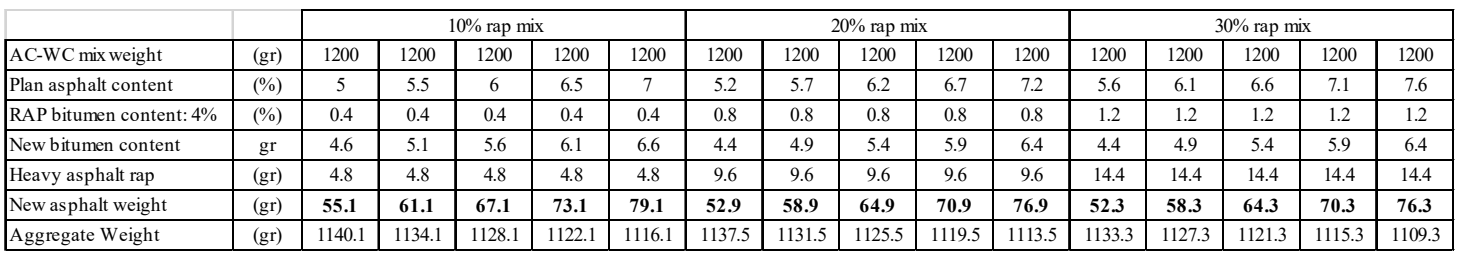

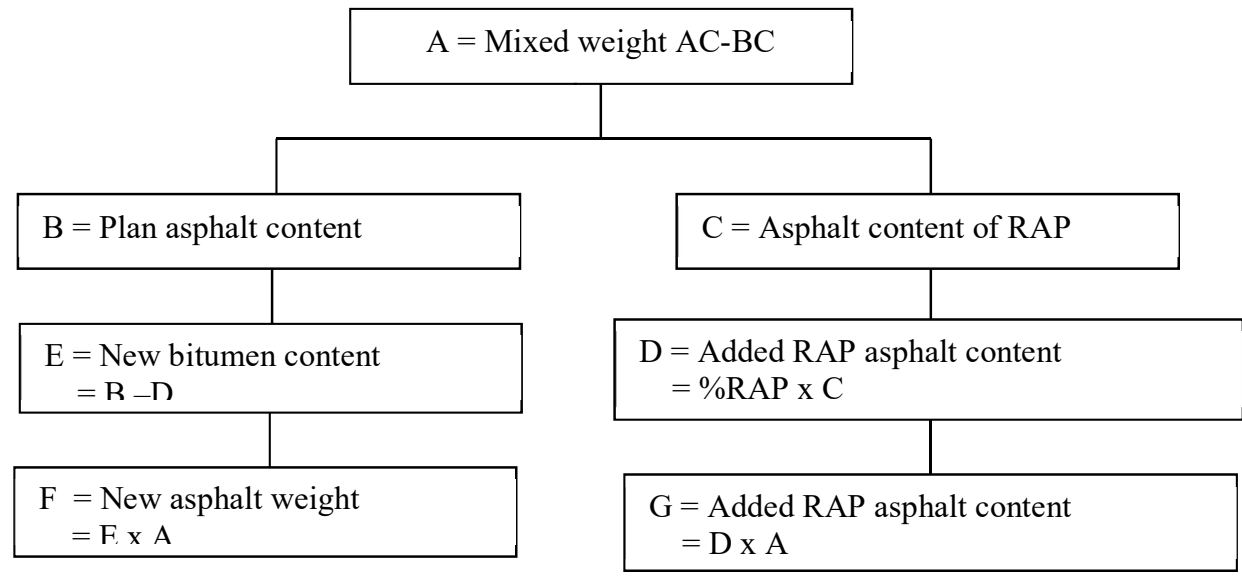

Figure 6. Calculation of Asphalt Bitumen Content Pen 60/70 added

\subsection{Result of Mixture}

\subsubsection{Result of Mixture Using RAP 10\%, Material 90\%}

The optimum asphalt bitumen content derived from the mixture properties is shown on figure

\begin{tabular}{|l|l|l|l|l|l|}
\hline Pass ratio 200 with (EAC) & & & & & \\
\hline VIM & & & & & \\
\hline VMA & & & & & \\
\hline VFB & & & & & \\
\hline Marshall Stability & & & & & \\
\hline Flow & & & & & \\
\hline Residual Marshall Stability & & & & & \\
\hline$\longrightarrow$ OAC & & \\
\hline \multicolumn{2}{|c|}{5} & & & & \\
\hline
\end{tabular}

Figure 7. Optimum asphalt content (OAC) of Mixture Using RAP 10\%, Material 90\%

Figure 7 shows that the the mixture using RAP $10 \%$, Material $90 \%$ had fulfilled the specification required which is $6 \%$. The characteristic of the mixture is shown on Table 9. 
Table 9. The characteristic of the mixture using RAP 10\%, Material $90 \%$

\begin{tabular}{|l|c|c|c|c|c|c|}
\hline \multirow{2}{*}{ Characteristic of the mixture } & \multirow{2}{*}{ Spec } & \multicolumn{5}{|c|}{ Plan Asphalt Content (\%) } \\
\cline { 3 - 7 } & & $\mathbf{4 , 6}$ & $\mathbf{5 , 1}$ & $\mathbf{5 , 6}$ & $\mathbf{6 , 1}$ & $\mathbf{6 , 6}$ \\
\hline $\begin{array}{l}\text { Sieve passed particle ratio 0,075 mm } \\
\text { with effective asphalt content }\end{array}$ & $0,6-1,6$ & 1.3 & 1.2 & 1.1 & 1 & 0.9 \\
\hline Void in Mix (VIM)(\%) & $3-5$ & 6.972 & 5.177 & 3.238 & 1.965 & 0.756 \\
\hline Void In Mineral Agreggate (VMA) (\%) & Min14 & 18.037 & 17.51 & 16.884 & 16.848 & 16.879 \\
\hline Void Filled With Bitument (VFB)(\%) & Min 65 & 61.348 & 70.434 & 80.821 & 88.370 & 95.522 \\
\hline Stabilitas Marshall (kg) & Min 800 & 865.328 & 905.981 & 842.097 & 760.791 & 696.908 \\
\hline Flow (mm) & $2-4$ & 3.4 & 3.55 & 3.75 & 4.1 & 4.2 \\
\hline $\begin{array}{l}\text { Residual Marshall Stability (\%) after } \\
\text { immersion for 24 hours, 60 }\end{array}$ & 90 & 90,697 & 91,261 & 91,386 & 90,785 & 89,479 \\
\hline
\end{tabular}

Source: Calculations

4.3.2 Result of Mixture Using RAP 20\%, Material 80\%

The optimum asphalt bitumen content derived from the mixture properties is shown on figure 8 .

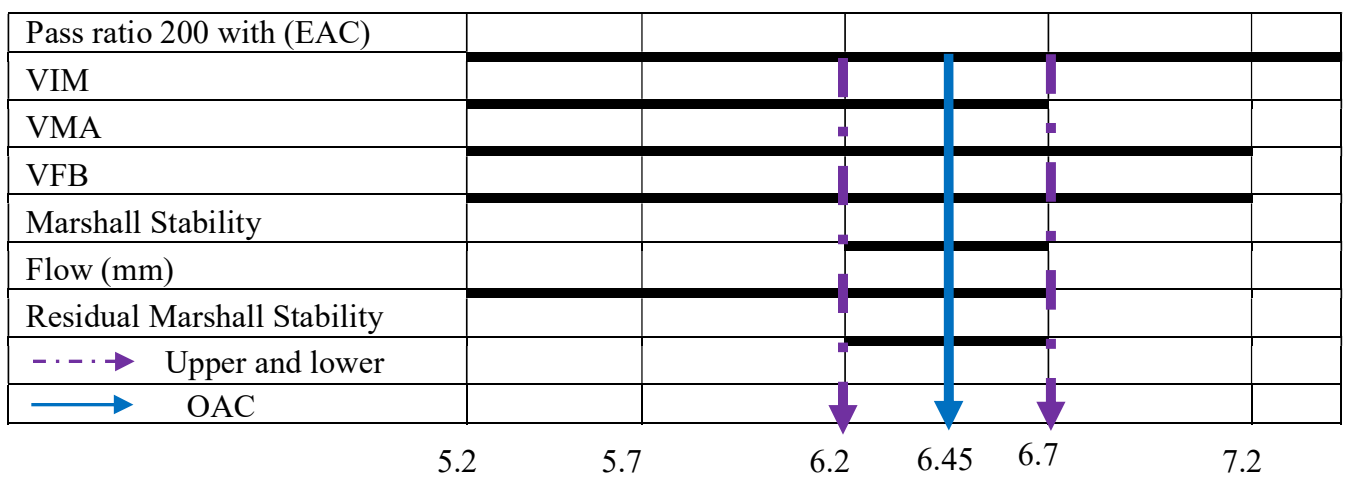

Figure 8. Optimum asphalt content (OAC) of Mixture Using RAP 20\%, Material 80\%

Figure 8 shows that the the mixture using RAP 10\%, Material 90\% had fulfilled the specification required which is $6.45 \%$. The characteristic of the mixture is shown on Table 10.

Table 10. The characteristic of the mixture using RAP 20\%, Material $80 \%$

\begin{tabular}{|l|c|c|c|c|c|c|}
\hline \multirow{2}{*}{ Characteristic of the mixture } & \multirow{2}{*}{ Specification } & \multicolumn{5}{|c|}{ Plan Asphalt Content (\%) (\%) } \\
\cline { 3 - 7 } & & $\mathbf{5 . 2}$ & $\mathbf{5 . 7}$ & $\mathbf{6 . 2}$ & $\mathbf{6 . 7}$ & $\mathbf{7 . 2}$ \\
\hline $\begin{array}{l}\text { Sieve passed particle ratio 0,075 } \\
\text { mm with effective asphalt content }\end{array}$ & $0,6-1,6$ & 1.4 & 1.2 & 1.1 & 1 & 0.9 \\
\hline Void in Mix (VIM)(\%) & $3-5$ & 8.721 & 6.689 & 3.783 & 6.674 & 2.128 \\
\hline $\begin{array}{l}\text { Void In Mineral Agreggate (VMA) } \\
\text { (\%) }\end{array}$ & Min14 & 17.595 & 16.851 & 16.541 & 16.364 & 16.114 \\
\hline $\begin{array}{l}\text { Void Filled With Bitument } \\
\text { (VFB)(\%) }\end{array}$ & Min 65 & 50.721 & 60.322 & 77.133 & 77.548 & 86.8 \\
\hline Stabilitas Marshall (kg) & Min 800 & 754.984 & 772.407 & 842.097 & 824.675 & 778.214 \\
\hline Flow (mm) & $2-4$ & 3.2 & 3.4 & 3.5 & 3.7 & 4.3 \\
\hline $\begin{array}{l}\text { Residual Marshall Stability }(\%) \\
\text { after immersion for } 24 \text { hours, } 60^{\circ} \mathrm{C}\end{array}$ & 90 & 90.500 & 91.330 & 90.400 & 91.320 & 90.290 \\
\hline
\end{tabular}

Source: Calculations 
4.3.3. Result of Mixture Using RAP 30\%, Material 70\%

The optimum asphalt bitumen content derived from the mixture properties is shown on figure 9 .

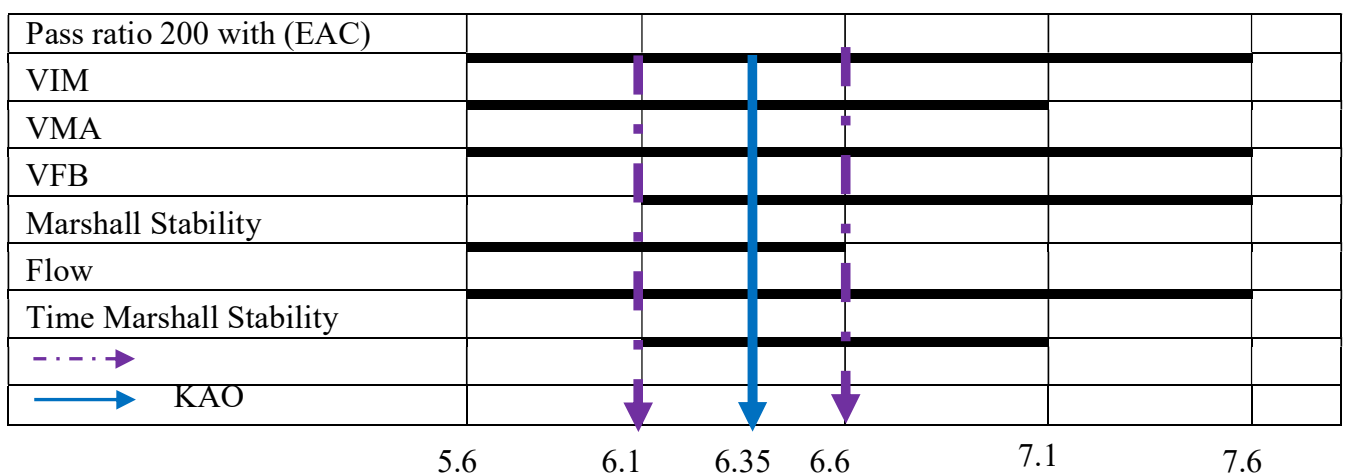

Figure 9. Optimum asphalt content (OAC) of Mixture Using RAP 30\%, Material 70\%

Figure 9 shows that the the mixture using RAP 10\%, Material $90 \%$ had fulfilled the specification required which is $6.35 \%$. The characteristic of the mixture is shown on Table 11 .

Table 11. The characteristic of the mixture using RAP 30\%, Material 70\%

\begin{tabular}{|l|c|c|c|c|c|c|}
\hline \multirow{2}{*}{$\begin{array}{c}\text { Characteristic of the } \\
\text { mixture }\end{array}$} & \multirow{2}{*}{ Specification } & \multicolumn{5}{c|}{ Plan Asphalt Content (\%) (\%) } \\
\cline { 3 - 7 } & $\mathbf{5 . 6}$ & $\mathbf{6 . 1}$ & $\mathbf{6 . 6}$ & $\mathbf{7 . 1}$ & $\mathbf{7 . 6}$ \\
\hline $\begin{array}{l}\text { Sieve passed particle ratio } \\
\text { 0,075 mm With effective } \\
\text { asphalt content }\end{array}$ & $0.6-1,6$ & 1.4 & 1.3 & 1.2 & 1.1 & 1 \\
\hline Void in Mix (VIM)(\%) & $3-5$ & 6.744 & 5.843 & 3.743 & 1.337 & 0.473 \\
\hline $\begin{array}{l}\text { Void In Mineral Agreggate } \\
\text { (VMA) (\%) }\end{array}$ & Min14 & 18.666 & 18.917 & 17.035 & 17.164 & 17.488 \\
\hline $\begin{array}{l}\text { Void Filled With Bitument } \\
\text { (VFB)(\%) }\end{array}$ & Min 65 & 63.868 & 69.114 & 78.040 & 92.209 & 97.296 \\
\hline Stabilitas Marshall (kg) & Min 800 & 807.252 & 836.290 & 853.712 & 766.599 & 691.101 \\
\hline Flow (mm) & $2-4$ & 3.3 & 3.40 & 6.35 & 3.7 & 4.0 \\
\hline $\begin{array}{l}\text { Remaining Marshall stability } \\
\text { (\%) after immersion for 24 } \\
\text { hours, 60 }\end{array}$ & 90 & 89.20 & 91.67 & 90.48 & 91.65 & 89.92 \\
\hline
\end{tabular}

Source: Calculations

\subsection{Analysis of RAP Mixture}

The RAP and new material composition are crusial affecting the mixture characteristic. The effect of RAP percentage in mixture for RAP 10\%; New Material 90\%, RAP 20\%; New Material $80 \%$ dan RAP 30\%; New Material 70\% is shown on figure 10 to 16 . 


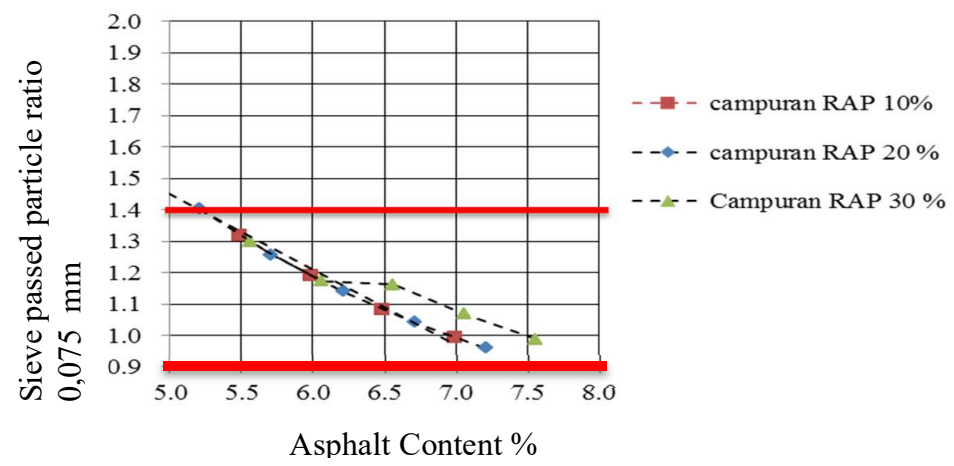

Figure10. Relationship Chart of RAP Mixture to Sieve passed particle ratio 0,075 $\mathrm{mm}$ with Optimum Asphalt Content

Figure 10 shows that the more RAP in mixture, the less Sieve passed particle ratio 0,075 and Optimum Asphalt Content.

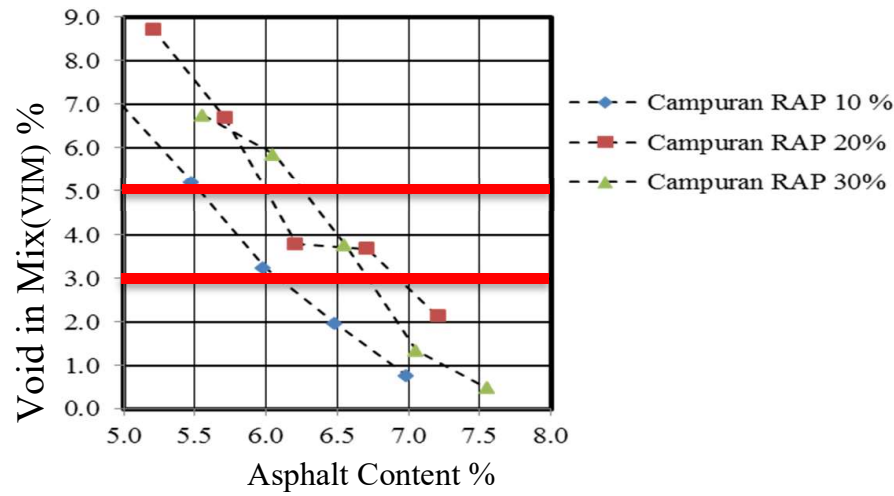

Figure 11. Relationship Chart of RAP Mixture to Void in Mixture (VIM).

Figure 11 shows that the RAP $10 \%$ of mixture resulting the lowest Void in Mixture (VIM) compared to RAP $20 \%$ and $30 \%$.

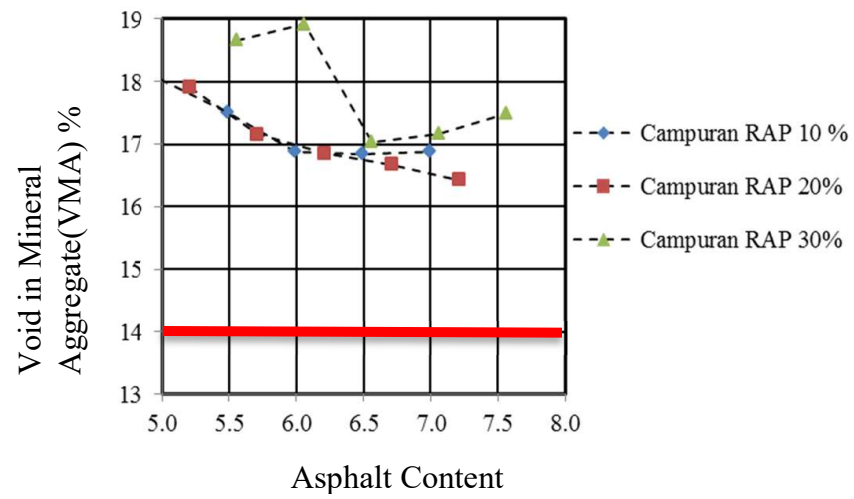

Figure 12. Relationship Chart of RAP Mixture to Void Mixture Aggregate (VMA).

Figure 12 shows that RAP $30 \%$ of mixture resulting the highest Void Mixture Aggregate (VMA) compared to RAP $20 \%$ and $30 \%$. 


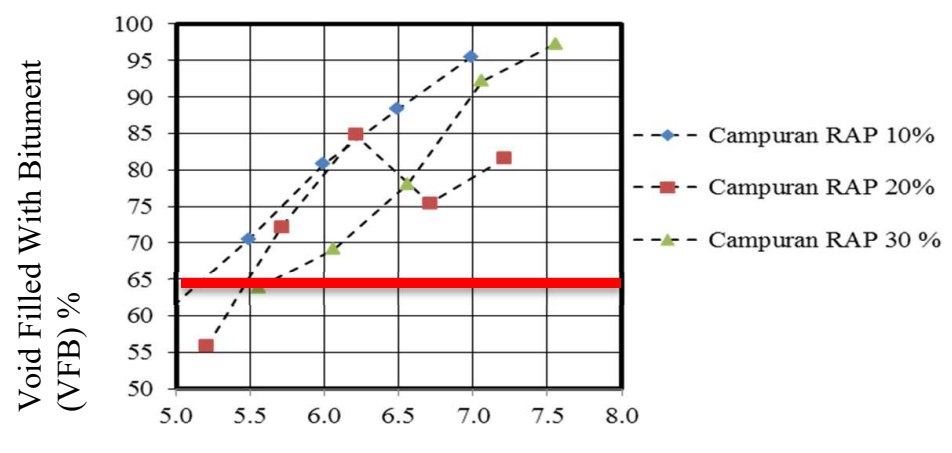

Asphalt Content \%

Figure 13. Relationship Chart of RAP Mixture to Void Filled Bitumen (VFB).

Figure 13 shows that RAP $20 \%$ of mixture did not fulfilled the bitumen content required for the lowest value.

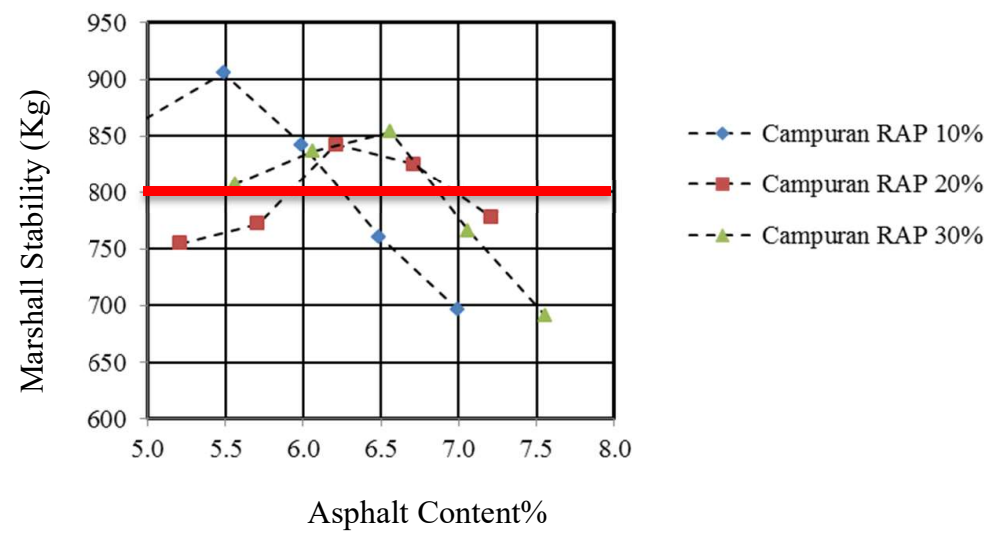

Figure 14. Relationship Chart of RAP Mixture to Marshall Stability.

Figure 14 shows that all of RAP mixture did not fulfilled the bitumen content required at the highest value.

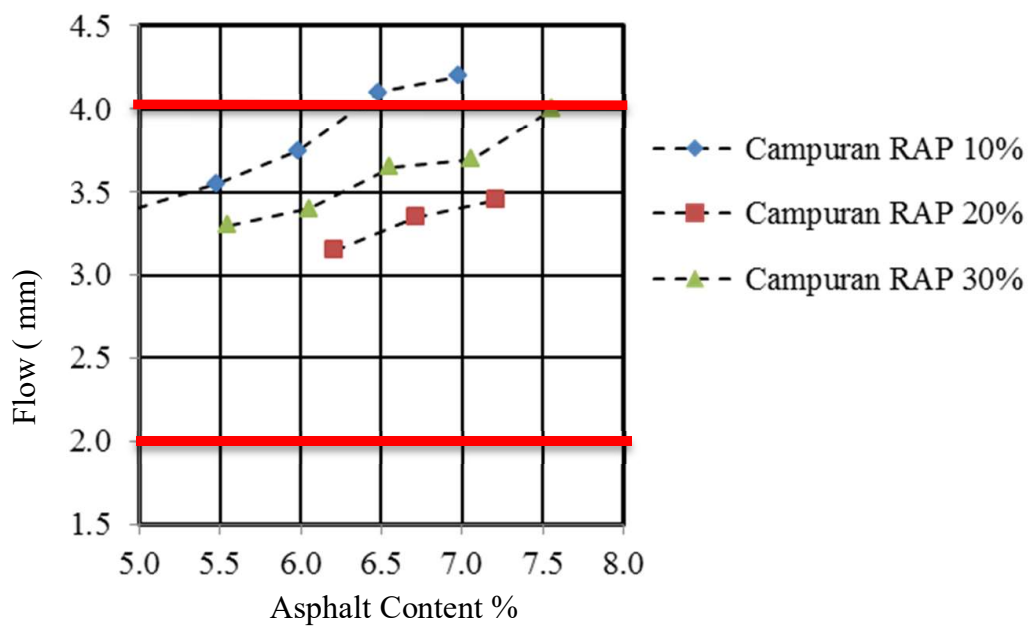

Figure 15. Relationship Chart of RAP Mixture to Flow. 
Figure 15 shows that all of the RAP mixture had fulfilled the bitumen content required except for RAP $10 \%$ mixture at the highest bitumen content value.

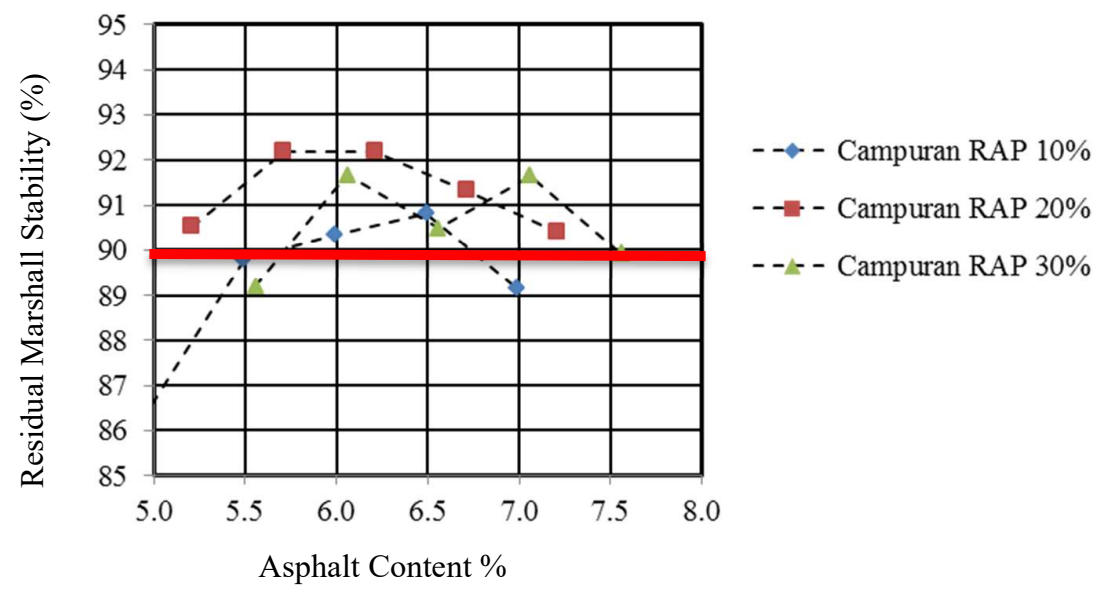

Figure 16. Relationship Chart of RAP Mixture to Residual Marshall Stability.

Figure 16 shows that all of RAP mixture had fulfilled the bitumen content required except for RAP 10\% and RAP 30\% mixture which did not fulfilled the bitumen content both at the highest and lowest value.

By comparing the characteristic of the result test of RAP 10\%, RAP $20 \%$ and RAP $30 \%$ mixture, it can be concluded that:

a. The more RAP percentage of AC-WC mixture for three Sieve passed particle ratio 0,075, the less Effective Asphalt Content resulted. For VIM and VFB, most of the mixture using RAP 10\% and RAP $30 \%$ had fulfilled the requirement. The VMA on all of RAP had fulfilled the requirement.

b. The more RAP percentage in AC-WC mixture, the flow value is decreasing significantly, but at RAP 30\% mixture, the bitumen content had risen.

\section{Conclusions and Suggestions}

\subsection{Conclusions}

1. The RAP characteristic which fulfill the requirement of the specification is specific gravity test 2,6 gr/cm3 and water absorption 1,78 \%, but RAP aggregate grading did not fulfill the grading envelope. The adding of new material aggregate is needed in order to fulfill the envelope grading required. The RAP characteristic for asphalt which fulfill the specification required is obtained from the extraction process of mixture with asphalt bitumen content $4 \%$.

2. From all of the RAP mixture, the most optimum result and fulfill the specification required is RAP $30 \%$; new material aggregate $70 \%$.

\subsection{Suggestions}

The further research is needed to study RAP usage in ACWC mixture in the field. By the direct field testing and observing for the certain time frame, the real condition of the pavement loaded with the traffic is obtained.

\section{REFERENCES}

[1] East Java Road Agency, "Penetapan Ruas-Ruas Jalan Menurut Statusnya Sebagai Jalan Provinsi,” Surabaya, 2016. [Online]. Available:

http://library1.nida.ac.th/termpaper6/sd/2554/19755.pdf. 
[2] R. Hasan, "Feasibility of Using High RAP Content in Hot Mix Asphalt," Melbourne.

[3] H. Budianto, Menuju Jalan Yang Andal. Surabaya: PT Cakra Daya Sakti, 2009.

[4] K. Aravind and A. Das, "Bituminous pavement recycling," Dep. Civ. Eng. IIT Kanpur, no. January 2006, pp. 1-3, 2006.

[5] E. P. Kusmarini, "Analisa Penggunaan Reclaimed Asphalt Pavement (RAP) Sebagai bahan Campuran Beraspal Panas dengan Menggunakan Aspal Pen 60-70 (Studi Kasus Jalan Nasional Gemekan-Jombang dan Jalan Nasional Pandaan - Malang)," 2013.

[6] Indonesia Constitution, Undang - Undang Republik Indonesia Nomor 38 Tahun 2004 Tentang Jalan. Indonesia.

[7] Government Law, Peraturan Pemerintah Nomor 34 Tahun 2006 Tentang Jalan. Indonesia.

[8] Directorate General of Highway, Panduan Pemeliharaan Jalan. Direktorat Jenderal Bina Marga Departemen Pekerjaan Umum. Indonesia, 2005.

[9] S. Sukirman, Perencanaan Tebal Struktur Perkerasan Jalan. Bandung: NOVA, 1992.

[10] Directorate General of Highway, Spesifikasi Umum Edisi 2018 Revisi 2. Indonesia, 2020.

[11] NAPA, Hot Mix Asphalt Materials Mixture Design and Construction. Maryland: NAPA Education Foundation, 1996. 